\section{Agricultural Research in Northern Nigeria}

THE Institute for Agricultural Research now covers the work of the Regional Research Station of the Ministry of Agriculture of Northern Nigeria, at Samaru, together with its sub-stations at Shika, Mokwa and Kano. From October 4, 1962, the Stations became the Institute for Agricultural Research, Ahmadu Bello University, and Prof. H. S. Darling was appointed as its director. The first annual report for the year ending March 31, 1963, is now available (Pp. $x+67$. Zaria, N. Nigeria: Institute for Agricultural Research and Special Services, Ahmadu Bello University, 1964. 10s.). Soil fertility and the improvement of crop yields are in the forefront of the Institute's programme, which covers crops important to the area, such as groundnuts and sorghum. Some success has been achieved in the yield of oilseed crops such as sesame, soya bean, groundnuts, sunflower and castor. Work in Bulgaria and Russia was not overlooked, and varieties of sunflower from these countries yielded seed of higher oil content than the older standard varieties. A considerable effort was devoted to the groundnut aflatoxin problem. This included experimentation with methods of drying and a study of the factors affecting contamination of the crop by Aspergillus flavus. It was concluded generally that seed from broken or termite-damaged pods was the main factor in contributing highly toxic groundnuts to the crop. Work on Pennisetum millets involved the trial of several varieties and the effect of spacing on yield and plant disease. The breeding selection and testing programme of the Cotton Breeding Section follows well-established lines. The maximum yield plot gave a yield in excess of $2,000 \mathrm{lb}$. per acre for the fifth successive year. The report is a record of excellent progress and a testimony to the good work done by the staff of the Tnstitute.

\section{Applied Mathematics at the Weizmann Institute of Science, Israel}

The autumn issue of Rehovoth (3, No. 3; 1964), a periodical published by the Weizmann Institute of Science and Yad Chaim Weizman, Rehovoth, Israel, is a special number devoted primarily to applied mathematies, particularly to some of the work now being carried out in the Applied Mathematics Department of the Institute under the direction of Prof. Chaim I. Pekeris, who founded the Department in 1948. He contributes a stimulating article entitled "A Brief History of the Department of Applied Mathematics". This is, however, far from being a parochial account of the subject from one centre of learning; it is a fascinating, if brief, discourse of a major revolution in seience: the drifting apart, after World War I, of pure mathematics, physics and applied mathematics. Fifty years ago, no distinction was made between an applied mathematician and a physicist; as examples are cited the work of Lord Rayleigh (1842-1919), a leading authority on applied mathematics, a Nobel prize-winner in physies (1904), and at the forefront of physical research all his life; also that "esoteric mathematician" David Hilbert (1862-1943), ". . . who was not only well versed in physics, but himself contributed to the theory of relativity and to the kinetic theory of gases"; again, Henri Poincaré (1854-1912), last of the giant "natural philosophers", whose profound contributions to pure mathematics, physics and astronomy are well known in the histories of these disciplines. Among many original and shrewd observations made by Prof. Pekeris in this article are: "Today, pure mathematicians receive little training in physics. In some universities one can get a Ph.D. in mathematics without ever having heard of the Second Law of Thermodynamies". He goes on to say that "The chosen audience of pure mathematicians is, clearly, made up of other pure mathematicians. Similarly, physicists, preocoupied with the atomic nucleus, concern themselves with little else". Remarking that
"... there is no peace in the foreseeable future for applied mathematicians", he lists some of the major problems confronting them "... when they can sit in their offices and, with the aid of electronic computers", proceed to their solution. The schedule includes forecasting weather by numerical analysis; prediction of the tides at every point of the world oceans on the basis of tidal theory alone; explanation on the basis of pure theory of every measured atomic and molecular spectral line; determination of the crystal structure of proteins from X-ray photographs; and interpretation of the significance of every wrinkle in a seismogram in terms of the nature of the explosion (nuclear or earthquake), and the internal constitution of the Earth. "Applied Mathematics, at the Weizmann Institute, ranges from the building and designing of computers, to the study of the internal constitution of the Earth and the prediction of ocean tides". This and other articles in this well-produced and illustrated magazine convey impressively an idea of what has been done in the past, and is now being done, in the realm of applied mathematics in its modern conception.

\section{Administrative Organization of the Soviet Construction Industry}

Ir may not be generally known that the Department of Scientific and Industrial Research, through its Overseas Liaison Group at Africa House, Kingsway, London, W.C.2, publishes from time to time, for open distribution, reports from United Kingdom Scientific Attachés and Advisers on matters of primary interest to those concerned with the administrative organization of various industries in foreign countries. One such report by T. Garrett, Scientific Attaché, Moscow (U.S.S.R. 32, August 1964), entitled "Administrative Organization of the Soviet Construction Industry", describes the functions and responsibilities of the various organizations concerned, especially those of the U.S.S.R. State Building Committee. This report is most informative and gives an insight into the problems which have hitherto beset, and still do face, the building industry in the Soviet Union. "Great demands are made on the Soviet construction industry and the co-ordination of this complex and widely dispersed organization which employs one-tenth of all Soviet industrial workers is a mammoth task. Following November 1962 . . . a number of administrative changes were put into effect, giving more power to the central bodies concerned with construction and relieving the local economic councils (Sovnarkhozy) of their responsibility for building operations. The aim was to reduce the growing number of unfinished and abandoned projects and the resultant waste of capital investment and also to improve co-ordination, bring about a unified technical policy in the construction industry and to make more effective use of available resources." The subject-matter of this report is dealt with under the following headings: the U.S.S.R. Council of Ministers; U.S.S.R. Supreme Economie Council (VSNKh); the Stato Building Committee (U.S.S.R. Gosstroi); Academies of Construction and Architecture; the Scientific and Technical Couneil; the Main State Construction Inspectorate; Project Organizations; the Republican Councils of Ministers; Republican Cosstroi; Republican Ministries of Construction; Main Construction Directorates; Contract Construction Organizations; the All-Union Capital Investments Bank (U.S.S.R. Stroibank); Party Committees; and the Plan for Capital Construction. The Soviet construction industry, despite this policy of centralization, is thus involved in a somewhat formidable maze of bureaucratic controls which is perhaps understandable having regard to the size and population of the country; fortunately, the report contains two explanatory appendixes, one giving a schematic diagram of the inter-relationships of the various organizations previously noted as now involved in the construction industry; the other, a diagram of the structure of U.S.S.R. 